\title{
PERENCANAAN STRUKTUR GEDUNG PERKANTORAN 7 LANTAI
}

\author{
${ }^{1}$ Tanjung Rahayu, ${ }^{2}$ Fandi Laode Sadikin \\ Program Studi Teknik Sipil Fakultas Teknik Universitas Suryakancana \\ tanjungrahayu@yahoo.com
}

\begin{abstract}
Abstrak
Gedung merupakan tempat untuk melakukan aktifitas dalam berbagai bidang, contohnya adalah gedung perkantoran. Dilihat dari fungsinya maka dibutuhkan ruang yang memadai agar kegiatan perkantoran nyaman dan aman. Dalam membangun sebuah gedung diperlukan perencanaan yang matang terutama dalam perencanaan strukturnya. Hasil analisis didapatkan mutu beton sebesar 25 MPa, mutu tulangan baja untuk diameter $<12 \mathrm{~mm}$ sebesar $240 \mathrm{MPa}$ dan diameter $>13 \mathrm{~mm}$ sebesar $390 \mathrm{MPa}$, pelat tangga dan bordes dengan tebal 150mm (tulangan 2D13), balok bordes dengan dimensi 250x300mm (tulangan 2D13 dan sengkang 010-120mm), balok penggantung lift dengan dimensi 250x300mm (tulangan 4D13 dan sengkang D13-100mm), pelat lantai dengan tebal $150 \mathrm{~mm}$ (tulangan arah $x$ 012-160 mm dan y 012-120 mm), balok BA1 dengan dimensi 300x450mm (tulangan tumpuan dan 2D25 dan sengkang 010-150mm), balok BA2 dengan dimensi 250x350mm (tulangan tumpuan dan 2D25 dan sengkang 010-150mm), balok B1 dengan dimensi 400x650mm (tulangan tumpuan 10D25, lapangan 5D25 dan sengkang D13-100mm), balok B2 dengan dimensi 300x500mm (tulangan tumpuan 6D25, lapangan 3D25 dan sengkang D13-130mm), balok B3 dengan dimensi 250x300mm (tulangan tumpuan 2D25, lapangan 2D25 dan sengkang 010-110mm), kolom $\mathrm{K} 1$ dengan dimensi $700 \times 700 \mathrm{~mm}$ (tulangan 36D25 dan sengkang 012-150mm), dan kolom K2 dengan dimensi 400x400mm menggunakan tulangan (tulangan 8D25 dan sengkang 012-150mm).
\end{abstract}

Kata kunci : Gedung, Perencanaan, Struktur, Gempa, SPRMK

\section{PENDAHULUAN}

Perencanaan struktur pada laporan tugas akhir ini bertujuan untuk merencanakan suatu struktur gedung yang dapat menahan beban- beban yang akan terjadi termasuk beban gempa dengan menggunakan salah satu sistem rangka pemikul momen yaitu Sistem Rangka Pemikul Momen Khusus (SPRMK). Dengan demikian, tujuan perencanaan suatu struktur untuk menghasilkan struktur yang kuat dan stabil dapat tercapai.

\section{A. Rumusan Masalah}

Permasalahan yang muncul adalah bagaimana merancang gedung yang berpedoman pada peraturan SNI 1726:2012, SNI 1727:2013 dan SNI 2847:2013 serta berapa dimensi struktur (balok, kolom, pelat) yang kuat menahan beban.

\section{B. Batasan Masalah}

Adapun batasan masalah dalam penulisan Laporan penelitian ini adalah sebagai berikut:

1. Peraturan yang digunakan dalam penelitian ini menggunakan SNI 1726:2012 untuk tata cara perencanaan ketahanan gempa, SNI 1727:2013 untuk standar beban minimum dan SNI 2847:2013 untuk persyaratan beton struktural yang digunakan untuk bangunan.
2. Perencanaan struktur pada tugas akhir ini menggunakan program bantu ETABS,SAP2000 dan spColumn.

3. Perencanaan hanya mencakup perencanaan struktur yang mencakup pelat, balok, dan kolom saja tanpa memperhitungkan fondasi, sloof dan dinding penahan tanah pada basemen

4. Perencanaan struktur plat lantai menggunakan metode manual dengan koefisien momen yang mengacu pada perbandingan bentang terpanjang dan terpendek.

5. Tidak memperhitungkan sistem utilitas bangunan, instalasi air bersih dan kotor, instalasi listrik serta finishing.

6. Tidak memperhitungkan RAB, metode pelaksanaan, RKS, dan time schedule.

\section{TINJAUAN PUSTAKA}

\section{A. Tulangan Pokok pada Pelat}

Perhitungan tulangan pelat didasarkan pada diagram tegangan-tegangan balok. Nilai $b$ pada lebar balok dianggap sebesar 1 meter. Langkah perhitungan untuk kebutuhan tulangan pelat adalah sebagai berikut.

1. Menentukan data-data d, fy, f'c, dan $\mathrm{Mu}$

2. Menentukan harga $\beta 1, \beta 1=0,85$ 
3. Menentukan batasan harga tulangan dengan menggunakan rasio tulangan yang disyaratkan

$$
\begin{aligned}
& \rho b=\frac{0,85 \cdot \beta 1 \cdot f^{\prime} c}{f y}\left(\frac{600}{600+f y}\right) \\
& \rho \max =0,025 \\
& \rho \max =0,75 \rho b \\
& \rho \min =\frac{0,25 x \sqrt{f^{\prime c} c}}{f y} \\
& \rho \min =\frac{1,4}{f y}
\end{aligned}
$$

Dari kedua harga pmin tersebut, diambil harga yang terkecil sebagai yang menentukan.

4. Mencari nilai momen nominal maksimal (Mn maks)

Mn maks $=$ As maks $x$ fy $x\left(d-\frac{a}{2}\right)$

5. Mencari nilai momen nominal perlu (Mn perlu)

$$
\text { Mn perlu }=\frac{M_{u}}{\phi}
$$

6. Memeriksa syarat tulangan

Mn maks > Mn perlu maka tidak perlu

menggunakan tulangan tekan

Mn maks < Mn perlu maka perlu menggunakan tulangan tekan

7. Menentukan harga $m$

$$
m=\frac{f y}{0,85 f c^{\prime}}
$$

8. Menentukan Rn

$$
R n=\frac{M n}{\emptyset b d^{2}}
$$

Diketahui harga $\varnothing=0,75$

9. Menghitung rasio tulangan yang dibutuhkan

$$
\rho=\frac{1}{m}\left(1-\sqrt{1-\frac{2 x m \times R n}{f y}}\right.
$$

Dimana : pmin < ppakai < pmax

10. Menentukan luas tulangan (AS) dari p perlu yang didapat

$$
\rho=\frac{A s}{b x d}
$$

11. Menentukan jumlah tulangan

$$
n \text { tulangan }=\frac{\text { Asperlu }}{\frac{1}{4} \times \pi x \emptyset^{2}}
$$

12. Menghitung momen nominal aktual yang dikalikan faktor reduksi (sumber: Istimawan D:1994)

Untuk Mn maks < Mn perlu

$\phi M n=\phi \times$ As $x$ fy $x(d-0,5 \times$ a $)+$ As' $x$ fy $x$ (d-d')

Untuk Mn maks > Mn perlu

$\phi \mathrm{Mn}=\phi \times$ As $\mathrm{x}$ fy $\mathrm{x}(\mathrm{d}-0,5 \mathrm{x}$ a)

Keterangan:

$$
\begin{array}{ll}
\text { As } & =\text { Luas tulangan Tarik } \\
\text { As' } & =\text { Luas tulangan tekan }
\end{array}
$$

Menentukan jarak antar tulangan (S pakai)

S pakai

$$
=\frac{b}{n \text { tulangan }}
$$

Keterangan:

$\mathrm{n}$ tulangan $=$ Jumlah tulangan pakai

b $\quad=$ lebar balok

\section{B. Perhitungan Tulangan Balok}

Menurut Dewobroto (2005), struktur beton untuk balok memerlukan tulangan baja pada sisi tarik untuk mengantisipasi kelemahannya terhadap tegangan tarik, tetapi pada umumnya penampang balok mempunyai tulangan baja pada kedua sisinya. Pada balok juga diperlukan tulangan sengkang untuk menahan gaya geser. Adapun perhitungan sebagai berikut:

Tahapan yang digunakan dalam menentukan tulangan lentur pelat adalah sebagai berikut:

1. Menentukan data-data d, fy, f'c, dan $\mathrm{Mu}$

2. Menentukan harga $\beta 1, \beta 1=0,85$

3. Menentukan batasan harga tulangan dengan menggunakan rasio tulangan yang disyaratkan

$$
\begin{aligned}
& \rho b=\frac{0,85 \cdot \beta 1 \cdot f^{\prime} c}{f y}\left(\frac{600}{600+f y}\right) \\
& \rho \max =0,025 \\
& \rho \max =0,75 \rho b \\
& \rho \min =\frac{0,25 x \sqrt{f^{\prime} c}}{f y} \\
& \rho \min =\frac{1,4}{f y}
\end{aligned}
$$

Dari kedua harga pmin tersebut, diambil harga yang terkecil sebagai yang menentukan.

4. Mencari nilai momen nominal maksimal (Mn maks)

$$
\text { Mn maks }=\text { As maks } x \text { fy } x\left(d-\frac{a}{2}\right)
$$

5. Mencari nilai momen nominal perlu (Mn perlu)

$$
\text { Mn perlu }=\frac{M_{u}}{\phi}
$$

6. Memeriksa syarat tulangan

Mn maks > Mn perlu maka tidak perlu

menggunakan tulangan tekan

Mn maks < Mn perlu maka perlu menggunakan tulangan tekan

7. Menentukan harga $m$

$$
m=\frac{f y}{0,85 f c^{\prime}}
$$

8. Menentukan Rn

$$
R n=\frac{M n}{\emptyset b d^{2}}
$$

Diketahui harga $\varnothing=0,75$

9. Menghitung rasio tulangan yang dibutuhkan 


$$
\rho=\frac{1}{m}\left(1-\sqrt{1-\frac{2 x m x R n}{f y}}\right.
$$

Dimana : pmin < ppakai < pmax

10. Menentukan luas tulangan (AS) dari p perlu yang didapat

$$
\rho=\frac{A s}{b x d}
$$

11. Menentukan jumlah tulangan

$$
n \text { tulangan }=\frac{\text { Asperlu }}{\frac{1}{4} x \pi x \emptyset^{2}}
$$

12. Menghitung momen nominal aktual yang dikalikan faktor reduksi (sumber: Istimawan D:1994)

Untuk Mn maks < Mn perlu

$\phi \mathrm{Mn}=\phi \times$ As $\mathrm{x}$ fy $\mathrm{x}(\mathrm{d}-0,5 \mathrm{x}$ a $)+$ As' $\mathrm{x}$ fy $\mathrm{x}$ (d-d')

Untuk Mn maks > Mn perlu

$\phi \mathrm{Mn}=\phi \times$ As $\mathrm{x}$ fy $\times(\mathrm{d}-0,5 \times \mathrm{a})$

Keterangan:

As = Luas tulangan Tarik

As' = Luas tulangan tekan

Menentukan jarak antar tulangan (S pakai)

$$
\text { S pakai }=\frac{b}{n \text { tulangan }}
$$

Keterangan:

$\mathrm{n}$ tulangan $=$ Jumlah tulangan pakai

b = lebar balok

Perencanaan penampang geser harus didasarkan sesuai SNI 2847:2013 pasal 11.1.1 (persamaan 1-11) yaitu harus memenuhi $\varnothing \mathrm{Vn}$ z Vu,

dimana:

$\mathrm{Vn} \quad=$ Kuat geser nominal penampang

$\mathrm{Vu}=$ kuat geser terfaktor pada penampang

$\mathrm{O}=$ reduksi kekuatan untuk geser $=0,75$

Kuat geser nominal merupakan sumbangan dari kuat geser beton $(\mathrm{Vc})$ dan tulangan (Vs)

$\mathrm{Vn}=\phi(\mathrm{Vc}+\mathrm{Vs})$

dan

$$
\begin{array}{ll}
\mathrm{Vc} & =0,17 \alpha \sqrt{f^{\prime} c b_{w} d} \\
\mathrm{Vs} & =\frac{V_{u}}{\emptyset}-\mathrm{Vc}
\end{array}
$$

dimana:

$\mathrm{Vc}=$ Kuat geser beton

Vs = Kuat geser nominal tulangan geser Untuk menentukan jarak antar tulangan (S pakai) digunakan perhitungan berikut

$$
\mathrm{S} \text { pakai }=\frac{b}{n \text { tulangan }}
$$

Keterangan:

$\begin{array}{ll}\mathrm{n} \text { tulangan } & =\text { Jumlah tulangan pakai } \\ \mathrm{b} & =\text { lebar balok }\end{array}$
Pengaruh torsi harus diperhitungkan apabila:

$$
T_{u} \leq \frac{\varphi \sqrt{f^{\prime} c}}{12}\left(\frac{A_{c p}{ }^{2}}{P_{c p}{ }^{2}}\right)
$$

Perencanaan penampang terhadap torsi:

$$
\mathrm{Tu} \leq \varnothing \mathrm{Tn} \quad(2.44)
$$

Tulangan sengkang puntir:

$$
T n=\frac{2 \cdot A_{0} \cdot A_{t} \cdot f_{y}}{s} \cot \theta
$$

dimana:

$\mathrm{Tu}=$ Momen torsi terfaktor

Tn = Kuat momen torsi

Tc $=$ Kuat torsi nominal yang disumbangkan oleh beton

A0 = Luas yang dibatasi oleh lintasan aliran geser $\mathrm{mm}^{2}$

\section{Perhitungan Tulangan Kolom}

Detail penulangan kolom akibat beban aksial tekan harus sesuai dengan SNI 2847:2013 pasal

21.3.5.1 sedangkan untuk perhitungan tulangan geser harus sesuai dengan SNI 2847:2013 pasal 23.5.1.

Berdasarkan Dewobroto (2013) perancangan kolom beton bertulang adalah sebagai berikut:

1. Input material properties

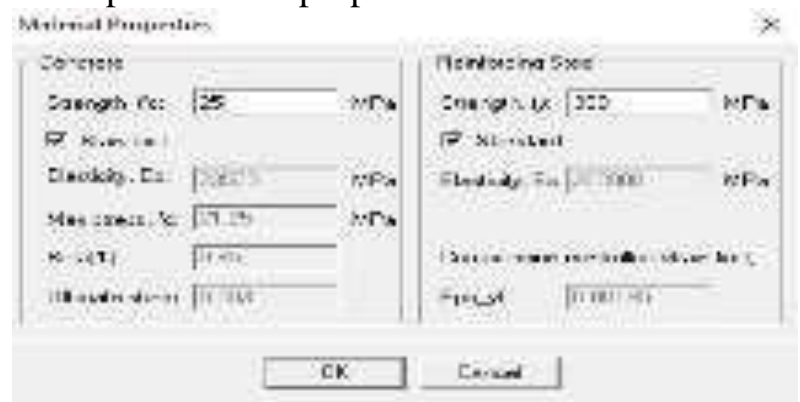

Gambar 2.4 Input material

2. Input ukuran kolom dan tulangan kolom

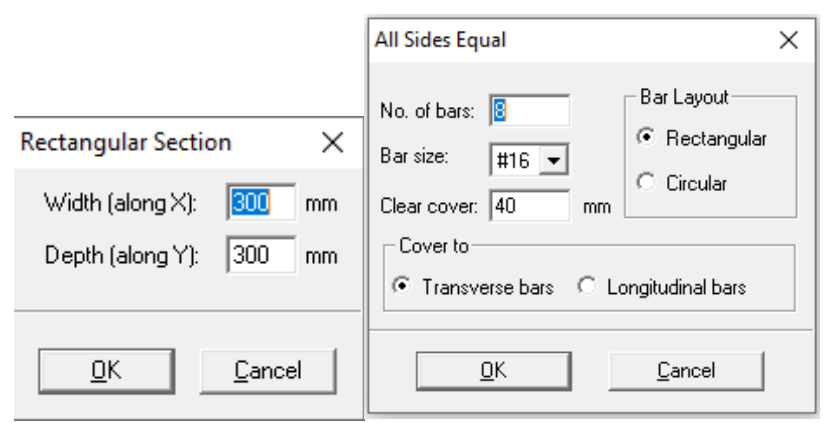

Gambar 2.5 Input ukuran dan tulangan Kolom 
3. Input pembebanan

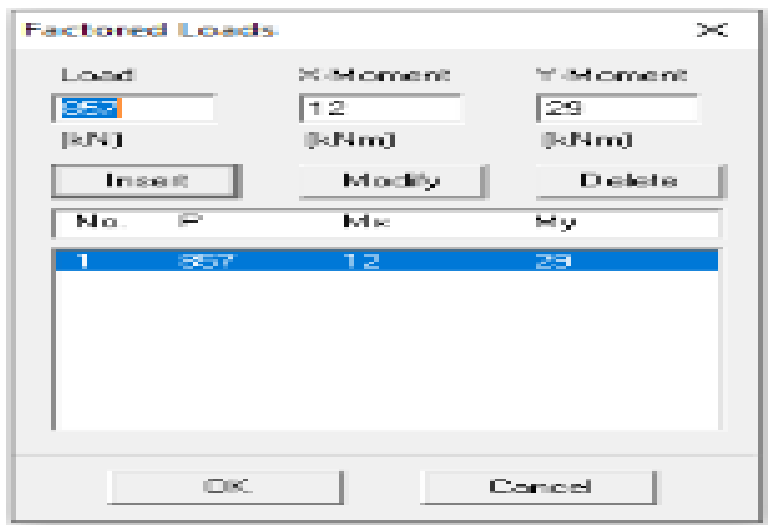

Gambar 2.6 Input pembebanan

4. Membuat diagram interaksi gaya normal dan momen biaksial kolom dengan menggunakan Spcolumn.

5. Cek kapasitas kolom untuk beban gaya normal dan momen terfaktor yang diperoleh dari kombinasi beton yang paling menentukan di setiap ujung kolom.

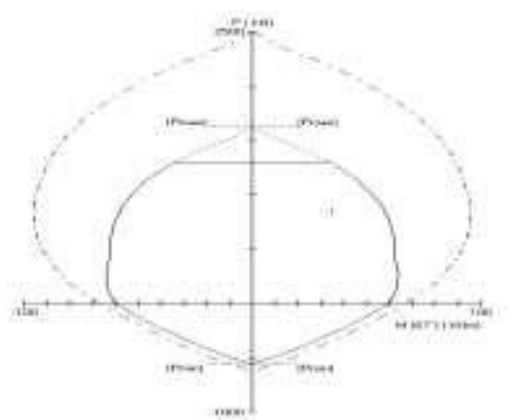

Gambar 2.7 Diagram Interaksi P-M

6. Cek Momen nominal kolom (Mn) $\mathrm{Mn}=(\mathrm{Mc}+$ $\mathrm{Ms}$ )

Keterangan:

$\mathrm{Mc}=$ Momen akibat gaya internal tekan beton $\mathrm{Ms}=$ Momen akibat gaya internal baja tulangan

7. Desain tulangan geser kolom $\mathrm{Vu}=\phi(\mathrm{Vc}+\mathrm{Vs})$ dan

$$
\mathrm{Vc}=\left(1+\left(\frac{\mathrm{Pu}}{14 \times \mathrm{Ag}}\right)\right) \sqrt{\frac{f c^{\prime}}{6}} x b x d
$$

dimana:

$\mathrm{Vc}=$ Kuat geser beton

$\mathrm{Vs}=$ Kuat geser nominal tulangan geser
3. METODOLOGI PENELITIAN

A. Diagram alir perencanaan

Tahapan perencanaan tugas akhir ini dapat dillihat pada Gambar 3.1 di bawah ini dan akan dijelaskan pada sub bab berikutnya.

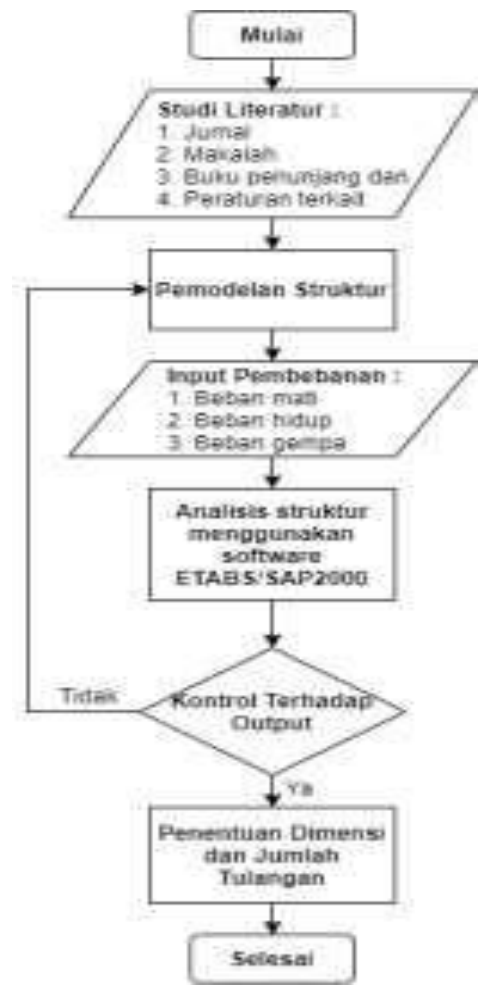

Gambar 3.1 Tahapan perencanaan metode penyelesaian tugas akhir

\section{B. Data Perencanaan}

Data perencanaan secara keseluruhan mencakup data umum bangunan serta data bahan yang diuraikan secara detail sebagai berikut:

1. Fungsi gedung : Gedung perkantoran

2. Lokasi : Bandung

3. Jumlah lantai : 7 lantai

4. Struktur bangunan: Beton bertulang

5. Sistem struktur : Sistem Rangka Pemikul Momen Khusus (SRPMK)

6. Tinggi gedung : 28,4 meter

7. Lebar gedung :40 meter

8. Panjang gedung : 31 meter

9. Tinggi tiap lantai :
a. Basemen
: 4,4 meter
b. Lantai 1-7 : 4 meter

10. Mutu bahan

a. Mutu beton (fc'): $25 \mathrm{MPa}(\mathrm{K}-300)$

b. Mutu baja
1) < 012 (fy) : $240 \mathrm{MPa}$
2) > D 13 (fy) : $390 \mathrm{MPa}$ 


\section{PEMBAHASAN}

\section{A. Perencanaan Tangga}

Tangga didesain dengan meletakan pelat bordes pada setengah tinggi antar lantai dengan denah tangga berbentuk huruf "U".

Perhitungan kebutuhan tulangan tangga digunakan berdasarkan momen maksimum yang terjadi antara pelat tangga dan bordes. Sehingga tulangan pelat tangga dan bordes menggunakan tulangan dan jarak yang sama. Perencanaan tulangan pelat tangga dilakukan dengan memperhitungkan $\phi \mathrm{Mn}$ harus lebih besar dari gaya dalam yang terjadi $(\mathrm{Mu})$. Hasil perhitungan tulangan untuk pelat tangga dan bordes arah x adalah $010-100 \mathrm{~mm}$ dan arah y adalah $010-250 \mathrm{~mm}$.

\section{B. Perencanaan Balok Bordes}

Perencanaan tulangan balok bordes dilakukan dengan memperhitungkan $\phi \mathrm{Mn}$ harus lebih besar dari gaya dalam yang terjadi $(\mathrm{Mu})$. Hasil perhitungan tulangan untuk balok bordes digunakan dimensi 250x300 mm dengan tulangan tumpuan atas 2D13, tulangan tumpuan bawah 2D13, tulangan lapangan atas 2D13, tulangan lapangan bawah 2D13, dan sengkang $010-120 \mathrm{~mm}$.

\section{Perencanaan Balok Lift}

Perencanaan balok penggantung lift dihitung berdasarkan jumlah reaksi yang terjadi pada balok lift. PPIUG 1983 pasal 3.3.(3) menyatakan bahwa beban keran yang membebani struktur pemikulnya terdiri dari berat sendiri keran ditambah muatan yang diangkatnya, dalam kedudukan keran induk dan keran angkat yang paling menentukan bagi struktur yang ditinjau. Sebagai beban rencana harus diambil beban keran tersebut dengan mengalikannya dengan suatu koefisien kejut yang ditentukan dengan rumus berikut,

$$
\Psi=(1+\mathrm{k} 1+\mathrm{k} 2 \times \mathrm{v}) \geq 1,15
$$

Perencanaan tulangan balok penggantung lift dilakukan dengan memperhitungkan $\phi \mathrm{Mn}$ harus lebih besar dari momen maksimal yang terjadi $(\mathrm{Mu})$. Hasil perhitungan tulangan untuk balok penggantung lift digunakan dimensi 250x300 mm dengan tulangan tumpuan atas 4D20, tulangan tumpuan bawah 2D13, tulangan lapangan atas 2D13, tulangan lapangan bawah 4D20, dan sengkang $\varnothing 10-120 \mathrm{~mm}$.

\section{Perencanaan Pelat}

Perhitungan momen yang terjadi $(\mathrm{Mu})$ yang bekerja pada pelat dengan menggunakan koefisien PBI 1971 tabel 13.3.2 untuk pelat dua arah terjepit penuh. Perencanaan tulangan pelat dilakukan dengan memperhitungkan $\phi \mathrm{Mn}$ harus lebih besar dari gaya dalam yang terjadi (Mu). Hasil perhitungan tulangan pelat lantai arah $\mathrm{x}$ tumpuan $\varnothing 12-160 \mathrm{~mm}$, arah x lapangan $\varnothing 12-160 \mathrm{~mm}$, arah y tumpuan $\emptyset 12-120 \mathrm{~mm}$, arah y lapangan $\emptyset 12-120 \mathrm{~mm}$,

\section{E. Perencanaan Balok Anak}

Balok anak ini direncanakan dapat memikul gayagaya maksimal yang terjadi pada setiap dimensi penampang serta dapat memenuhi persyaratan yang berlaku pada SNI 2847 : 2013.

Hasil perhitungan tulangan untuk balok anak BA1 digunakan dimensi 300x450 mm dengan tulangan tumpuan atas 2D25, tulangan tumpuan bawah 2D25, tulangan lapangan atas 2D25, tulangan lapangan bawah 2D25, dan sengkang $\varnothing 10-150$ $\mathrm{mm}$. Hasil perhitungan tulangan untuk balok anak BA2 digunakan dimensi 250x300 $\mathrm{mm}$ dengan tulangan tumpuan atas 2D25, tulangan tumpuan bawah 2D25, tulangan lapangan atas 2D25, tulangan lapangan bawah 2D25, dan sengkang Ø10 $-150 \mathrm{~mm}$.

\section{F. Perencanaan Balok Induk}

Balok anak ini direncanakan dapat memikul gayagaya maksimal yang terjadi pada setiap dimensi penampang serta dapat memenuhi persyaratan yang berlaku pada SNI 2847 : 2013. Hasil perhitungan tulangan untuk balok anak B1 digunakan dimensi 400x650 mm dengan tulangan tumpuan bawah 10D25, tulangan lapangan atas 10D25, tulangan lapangan bawah 5D25, tulangan lapangan atas 5D25, dan sengkang D13 - $100 \mathrm{~mm}$. Hasil perhitungan tulangan untuk balok anak BA2 digunakan dimensi 300x500 $\mathrm{mm}$ dengan tulangan tumpuan atas 6D25, tulangan tumpuan bawah $6 \mathrm{D} 25$, tulangan lapangan atas 3D25, tulangan lapangan bawah 3D25, dan sengkang D13 - 130 $\mathrm{mm}$. Hasil perhitungan tulangan untuk balok anak BA2 digunakan dimensi 250x300 $\mathrm{mm}$ dengan tulangan tumpuan atas 2D25, tulangan tumpuan bawah 2D25, tulangan lapangan atas 2D25, tulangan lapangan bawah 2D25, dan sengkang $\emptyset 10$ $-110 \mathrm{~mm}$.

\section{G. Perencanaan Kolom}

Kolom direncanakan dapat memikul gaya- gaya yang terjadi serta dapat memenuhi persyaratan yang berlaku pada SNI 2847 : 2013. Hasil perhitungan tulangan untuk kolom K1 digunakan dimensi 700x700 mm dengan tulangan 8D25 dan sengkang $\varnothing 12-150$. Hasil perhitungan tulangan untuk kolom $\mathrm{K} 2$ digunakan dimensi $350 \times 350 \mathrm{~mm}$ dengan tulangan 36D25 dan sengkang Ø12 - 150 .

\section{H. Hubungan Balok Kolom}

Hubungan balok kolom perlu dikontrol untuk mengecek tegangan yang terjadi. Hubungan tersebut harus mempunyai cukup kekuatan, kekakuan, dan dapat memberikan kebutuhan daktalitas yang disyaratkan. Hasil perhitungan hubungan balok B1 - kolom K2 yaitu digunakan 
3 D13-100 mm. Hasil perhitungan hubungan balok B2 - kolom K2 yaitu digunakan 3 D13-100 mm. Hasil perhitungan hubungan balok B3 - kolom K1 yaitu digunakan $3 \varnothing 12-100 \mathrm{~mm}$.

\section{KESIMPULAN DAN SARAN}

\section{A. Kesimpulan}

Berdasarkan hasil perencanaan struktur beton bertulang, maka dapat kesimpulan sebagai berikut:

1. Dimensi pelat tangga digunakan tebal pelat $150 \mathrm{~mm}$ dengan penulangan sebagai berikut:

a. Tulangan tumpuan pelat tangga arah $\mathrm{x}$ : Ø10-100 mm.

b. Tulangan tumpuan pelat tangga arah y : $\varnothing 10-250 \mathrm{~mm}$.

c. Tulangan lapangan pelat tangga arah $\mathrm{x}$ : Ø10-100 mm.

d. Tulangan lapangan pelat tangga arah y : $\varnothing 10-250 \mathrm{~mm}$.

2. Dimensi pelat bordes digunakan tebal pelat $150 \mathrm{~mm}$ dengan penulangan sebagai berikut:

a. Tulangan pelat bordes arah $\mathrm{x}: \varnothing 10-100$ $\mathrm{mm}$.

b. Tulangan pelat bordes arah y : $\varnothing 10-250$ $\mathrm{mm}$.

3. Balok bordes menggunakan dimensi 250x300 mm dengan penulangan sebagai berikut :
a. Tulangan tumpuan balok bordes atas/bawah : 2D $13 \mathrm{~mm}$
b. Tulangan lapangan balok bordes atas/bawah : 2D $13 \mathrm{~mm}$
c. Tulangan geser : 10-120 mm.

4. Balok penggantung lift menggunakan dimensi 250x300 $\mathrm{mm}$ dengan penulangan sebagai berikut :
a. Tulangan tumpuan balok penggantung lift atas: 4D $20 \mathrm{~mm}$.
b. Tulangan tumpuan balok penggantung lift bawah: 2D $13 \mathrm{~mm}$.
c. Tulangan lapangan balok penggantung lift atas: 2D $13 \mathrm{~mm}$.
d. Tulangan lapangan balok penggantung lift bawah: 4D $20 \mathrm{~mm}$.
e. Tulangan geser: D13-100 mm.

5. Dimensi pelat tangga digunakan tebal pelat
$150 \mathrm{~mm}$ dengan penulangan sebagai berikut

a. Tulangan tumpuan pelat tangga arah $\mathrm{x}$ : $\varnothing 12-160 \mathrm{~mm}$.

b. Tulangan tumpuan pelat tangga arah y: $\varnothing 12-160 \mathrm{~mm}$.

c. Tulangan lapangan pelat tangga arah $\mathrm{x}$ : $\varnothing 12-120 \mathrm{~mm}$.

e. Tulangan lapangan pelat tangga arah y: $\varnothing 12-120 \mathrm{~mm}$.

6. Balok anak (BA1) menggunakan dimensi $300 \times 450 \mathrm{~mm}$ dengan penulangan sebagai berikut :
a. Tulangan tumpuan balok anak atas: 2 D25 $\mathrm{mm}$.
b. Tulangan tumpuan balok anak bawah: 2D25 mm.
c. Tulangan lapangan balok anak atas: 2D25 $\mathrm{mm}$.
d. Tulangan lapangan balok anak bawah: 2D25 mm.
e. Tulangan geser : $\varnothing 10-150 \mathrm{~mm}$

7. Balok anak (BA2) menggunakan dimensi 250x350 mm dengan penulangan sebagai berikut :
a. Tulangan tumpuan balok anak atas: 2D25 $\mathrm{mm}$
b. Tulangan tumpuan balok anak bawah: 2D25 mm
c. Tulangan lapangan balok anak atas: 2D25 $\mathrm{mm}$
d. Tulangan lapangan balok anak bawah: 2D25 mm
e. Tulangan geser: $\varnothing 10-110 \mathrm{~mm}$

8. Balok induk (B1) menggunakan dimensi $400 \times 650 \mathrm{~mm}$ dengan penulangan sebagai berikut:
a. Tulangan tumpuan balok anak atas: 10 D25 $\mathrm{mm}$
b. Tulangan tumpuan balok anak bawah: 10 D25 mm
c. Tulangan lapangan balok anak atas: 5 D25 $\mathrm{mm}$
d. Tulangan lapangan balok anak bawah : 5 D25 mm
e. Tulangan torsi: $2 \mathrm{D} 13 \mathrm{~mm}$
f. Tulangan geser: D13-100 mm

9. Balok induk (B2) menggunakan dimensi $300 \times 500 \mathrm{~mm}$ dengan penulangan sebagai berikut:
a. Tulangan tumpuan balok anak atas: 6D25 $\mathrm{mm}$. 
b. Tulangan tumpuan balok anak bawah: $6 \mathrm{D} 25 \mathrm{~mm}$.

c. Tulangan lapangan balok anak atas: 3D25 $\mathrm{mm}$.

d. Tulangan lapangan balok anak bawah: 3D25 mm.

e. Tulangan torsi: $2 \mathrm{D} 13 \mathrm{~mm}$.

f. Tulangan geser: D13-100 mm

10. Balok induk (B3) menggunakan dimensi 250x300 mm dengan penulangan sebagai berikut:

a. Tulangan tumpuan balok anak bawah: 10D25 mm.

b. Tulangan lapangan balok anak atas: 5D25 $\mathrm{mm}$.

c. Tulangan lapangan balok anak bawah: 5D25 mm.

d. Tulangan torsi: $2 \mathrm{D} 13 \mathrm{~mm}$.

e. Tulangan geser: D13-100 mm.

11. Kolom (K1) menggunakan dimensi 700x700 $\mathrm{mm}$ dengan penulangan sebagai berikut:

a. Tulangan longitudinal: 36D25 mm.

b. Tulangan sengkang: $\varnothing 12-150 \mathrm{~mm}$.

12. Kolom (K2) menggunakan dimensi 400x400 $\mathrm{mm}$ dengan penulangan sebagai berikut:

a. Tulangan longitudinal: $4 \mathrm{D} 25 \mathrm{~mm}$.

b. Tulangan sengkang: $\varnothing 12-150 \mathrm{~mm}$.

\section{B. Saran}

Adapun saran-saran dalam pengerjaan penelitian ini yaitu:

1. Penggunaan analisis beban gempa statik ekivalen memberikan keterbatasan dalam desain model yang di analisis, terutama dalam hal tinggi bangunan. Untuk pengembangan studi lebih lanjut dapat digunakan analisis dinamik non linier untuk struktur bangunan yang lebih tinggi;

2. Sangat penting untuk memperhitungkan pengaruh gempa pada suatu perencanaan bangunan gedung dan mengaplikasikannya pada daerah yang rawan gempa tersebut.

\section{DAFTAR PUSTAKA}

Badan standardisasi nasional. (2012). SNI 1726:2012 TATA CARA PERENCANAAN KETAHANAN GEMPA UNTUK STRUKTUR BANGUNAN GEDUNG DAN NON GEDUNG. Jakarta.

Cara Membuat Rumah Kayu Sederhana Nan Cantik, Hemat Biaya! (2019, NOV 28).

Departemen Pekerjaan Umum. (2002). SNI 03 1729 - 2002 TATA CARA PERENCANAAN STRUKTUR BAJA

\section{UNTUK BANGUNAN GEDUNG}

Departemen Pekerjaan Umum.

Dewobroto, W. (2005). Evaluasi Kinerja Struktur Baja Tahan Gempa dengan Analisa Pushover. Banten: Universitas Pelita Harapan Indonesia.

Hadi, B. K. (2010, Desember 25). Teori Kestabilan Struktur. Retrieved from blogmukhlason.wordpress.com: https://blogmukhlason.wordpress.com/201 0/12/25/teori-kestabilan-struktur/

Hanggoro, A., \& Chusnul, C. (2015). Short Course Aplikasi SNI Terbaru untuk Mahasiswa Tugas Akhir. Semarang: Universitas Negeri Semarang.

Dipohusodo, Istimawan. 1994. Struktur Beton Bertulang. Jakarta: Gramedia pustaka utama.

Indarto. (2013). Sistem Informasi Geografis. Yogyakarta: Graha Ilmu.

Schodek, D. L. (1998). Struktur. Bandung: PT. Refika Aditama.

Sistem Struktur Rangka Baja. (2010, Oktober). Retrieved from angryits.blogspot.com: http://angryits.blogspot.com/2010/10/siste m-struktur-rangka-baja.html

Standar Nasional Indonesia. (2013). SNI 1727:2013 Beban minimum untuk perancangan bangunan gedung dan struktur lain. Jakarta.

Standar Nasional Indonesia. (2013). SNI 2847:2013 Persyaratan beton struktural untuk bangunan gedung. Jakarta.

Wibowo, A. P. (2012). PERENCANAAN STRUKTUR GEDUNG BETON BERTULANG. Yogyakarta: UNIVERSITAS NEGERI YOGYAKARTA.

Widodo, J. (2001). Etika Birokrasi Dalam Pelayanan Publik. Malang: CV. Malang: CV. Citra Malang

Konstruksi Baja Komposit. (2018). Retrieved from www.spesialiskonstruksi.com: https://www.spesialiskonstruksi.com/2018/ 12/konstruksi-baja-komposit.html

Kristianto, A. (2016). Perkuatan kolom beton bertulang bangunan rumah tinggal tahan gempa dengan menggunakan pen-binder (Tahun ke-2 dari rencana 2 tahun). Bandung: Universitas Kristen Maranatha.

Membuat Struktur Kolom Beton Pada Gedung Bertingkat. (n.d.). Retrieved from www.kolomsatu.com: https://www.kolomsatu.com/membuatstruktur-kolom-beton-pada-gedungbertingkat.html

Nadeak, L. (2016). ANALISIS DESAIN GEDUNG WHIZ HOTEL METODE SISTEM 
RANGKA PEMIKUL MOMEN KHUSUS. LAMPUNG: UNIVERSITAS LAMPUNG.

National Geographic Indonesia. (2012). Hidup Mati di Negeri Cincin Api.

Panitia pembaruan peraturan beton bertulang indonesia. (1981). PERATURAN PEMBEBANAN INDONESIA UNTUK GEDUNG

1983. Bandung: Yayasan Lembaga Penyelidikan Masalah Bangunan Pertama (Stensil).

Pawirodikromo, W. ((2012)). Seismologi Teknik \& Rekayasa Kegempaan. Yogyakarta: Pustaka Pelajar.

Priyonggo, G.(2016). PERANCANGAN ULANG GEDUNG SKYSUITES. Surabaya: Institut Teknologi Sepuluh Nopember.

Sampakang, J. J., \& et al. (2013). Perencanaan Sistem Rangka Pemikul Momen Khusus Pada Komponen Balok-Kolom Dan Sambungan Struktur Baja Gedung BPJN XI. Jurnal Sipil Statik, Vol. 1 No. 06 